\title{
Kepemilikan Asing Memoderasi Pengaruh Kualitas Laporan Keuangan dan Efisiensi Investasi
}

\author{
I Gusti Ayu Ary Meitari ${ }^{1}$ \\ Fakultas Ekonomi dan Bisnis \\ Universitas Udayana, Indonesia
}

\author{
Ida Bagus Putra Astika ${ }^{2}$ \\ Fakultas Ekonomi dan Bisnis \\ Universitas Udayana, Indonesia
}

\section{Surel : arymeitari05@gmail.com}

ABSTRAK

Perusahaan pertambangan sebagai salah satu sektor usaha, membutuhkan modal yang besar serta melaksanakan proyek dalam jangka waktu yang lama. Sehingga, perusahaan perlu menggunakan modal yang dimiliki secara efisien agar investasi yang dilakukan memberikan keuntungan maksimal bagi perusahaan. Untuk itu, perusahaan diharapkan memperhatikan faktor-faktor yang mempengaruhi efisiensi investasi. Tujuan dari penelitian ini adalah untuk mengetahui pengaruh kualitas laporan keuangan dan kepemilikan asing pada efisiensi investasi. Penelitian ini menggunakan data sekunder 15 perusahaan tambang. Jumlah tersebut diperoleh dengan metode purposive sampling dari 42 perusahaan tambang yang ada di Bursa Efek Indonesia (BEI). Periode pengamatan selama tiga tahun yaitu 2014 sampai 2016 sehingga diperoleh sebanyak 45 sampel penelitian. Berdasarkan hasil yang diperoleh menggunakan regresi linier sederhana dan moderated regression analysis ditemukan bahwa kualitas laporan keuangan berpengaruh positif pada efisiensi investasi dan kepemilikan asing memoderasi atau memperkuat pengaruh kualitas laporan keuangan pada efisiensi investasi.

Kata Kunci: Efisiensi Investasi; Kualitas Laporan Keuangan; Kepemilikan Asing.

\section{Foreign Ownership Moderates Effect of Financial Report Quality and Investment Efficiency}

\begin{abstract}
Mining company is part of the industrial sector, need large capital and also work on long-term projects. Mining company need to use their capital efficiently so that company can obtain maximum income from operational activities. To realize that, mining company need to concern on factors that affect investment efficiency. The purpose of this study examines the influence of the quality of financial reporting and foreign ownership on investment efficiency. The sample was obtained by purposive sampling method from 42 mining companies listed on the Indonesia Stock Exchange (IDX) and found 45 samples of observation from 2014-2016. Based on the analysis using simple linear regression and moderate regression analysis shows that the quality of financial reporting has a positive effect on investment efficiency and foreign ownership has a role to strengthen the influence of the quality of financial reporting on investment efficiency.
\end{abstract}

Keywords: Investment Efficiency; The Quality Of Financial Reporting; Foreign Ownership.

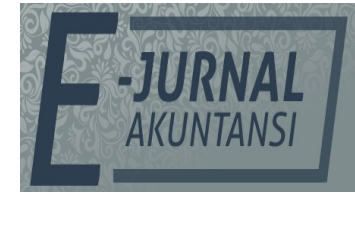

e-ISSN 2302-8556

Vol. 31 No. 8

Denpasar, Agustus 2021

Hal. 1973-1986

DOI:

10.24843/EJA.2021.v31.i08.p08

PENGUTIPAN:

Meitari, I.G.A.A., \& Astika, I.B.P. (2021). Kepemilikan Asing Memoderasi Pengaruh

Kualitas Laporan Keuangan dan Efisiensi Investasi. EJurnal Akuntansi, 31(8), 1973-

1986

RIWAYAT ARTIKEL: Artikel Masuk: 27 September 2018 Artikel Diterima: 18 Juni 2021

Artikel dapat diakses : https://ojs.unud.ac.id/index.php/Akuntansi/index 


\section{PENDAHULUAN}

Kegiatan investasi penting dilakukan oleh perusahaan karena dapat berpengaruh pada peningkatkan nilai perusahaan serta memberikan peluang untuk memperoleh keuntungan di masa mendatang dengan memanfaatkan modal yang dimiliki saat ini. Misalnya dengan pembelian alat-alat produksi untuk meningkatkan produksi, membeli surat-surat berharga, atau mendirikan pabrik baru untuk perluasan usaha. Perusahaan tentu berharap bahwa investasi yang dilakukan tidak berdampak negatif atau berdampak pada turunnya nilai perusahaan di masa mendatang. Sehingga, efisiensi dibutuhkan dalam investasi agar investasi yang dilakukan mendatangkan keuntungan yang maksimal serta terhindar dari kerugian (Emayanti, 2016).

Efisiensi investasi akan terjadi ketika investasi yang dilakukan oleh perusahaan memberikan dampak baik bagi perusahaan berupa penambahan laba sesuai yang diharapkan oleh perusahaan. Efisiensi investasi dapat mencerminkan tingkat kemampuan perusahaan dalam ketepatannya mengolah modal yang dimiliki saat ini untuk memberikan keuntungan di masa mendatang. Menurut Sari \& Suaryana (2014) tingkat investasi yang optimal dari perusahaan, dan investasi tersebut merupakan jenis investasi yang menguntungkan bagi perusahaan. Apabila perusahaan tidak melakukan investasi dengan optimal, yaitu berinvestasi melebihi atau kurang dari optimal maka dapat dikatakan telah terjadi inefisiensi investasi.

Investasi yang tidak optimal dapat terjadi pada perusahaan di sektor manapun. Dari berbagai sektor industri yang ada, pertambangan adalah salah satunya, dimana perusahaan pada sektor ini cukup banyak yang go public sehingga tercatat di Bursa Efek Indoensia (BEI). Industri tambang secara umum tidak terlepas dari kebutuhan modal yang besar, biaya operasional terkait dengan eksplorasi, dan juga permasalahan lingkungan yang ditimbulkan. Perusahaan tambang merupakan jenis usaha yang membutuhkan teknologi yang canggih, akses pasar, serta modal yang kuat untuk menunjang operasionalnya (Republika, 2017).

Menurut Willan (2013) industri tambang juga ditandai dengan adanya fluktuasi harga komoditas di pasaran yang mengakibatkan ketidakpastian sektor pertambangan. Misalnya pada tahun 2015 terjadi penurunan kapitalisasi sektor tambang di Indonesia sebesar 37\% dari tahun sebelumnya yang diakibatkan penurunan harga komoditas, sehingga perusahaan tambang di Indonesia diharapkanmeningkatkan perhatiannyadalam hal produktivitas, pengurangan biaya, dan disiplin modal (PwC, 2015).

Perusahaan tambang memiliki karakteristik yang berbeda dibandingkan perusahaan di sektor lainnya.Selain membutuhkan modal yang besar dan menghadapi fluktuasi harga komoditas, investasi proyek tambang juga mengerjakan proyek dalam jangka waktu yang panjang, untuk pengembalian modalnya tidak dapat dilakukan dalam waktu singkat, apabila proyek yang dikerjakan tidak mengedepankan managemen proyek yang baik, maka dapat mengakibatkan kebangkrutan (Mith, 2017). Berdasarkan hal tersebut memperlihatkan bahwa perusahaan tambang menghadapi risiko yang lebih besar dibandingkan perusahaan sektor lainnya dalam menjalankan bisnisnya, sehingga perusahaan tambang perlu melakukan investasi seefisien mungkin. 
Berdasarkan penelitian-penelitian sebelumnya, terdapat beberapa hal yang memiliki pengaruh pada efisiensi investasi, salah satunya adalah kualitas laporan keuangan. Ditemukan bahwa terdapat hubungan antara kualitas laporan keuangan dengan tingkat efisiensi investasi (Li \& Wang, 2010) dan (Firth et al., 2015). Biddle et al. (2009) mengungkapkan bahwa apabila kualitas laporan keuangan tinggi maka penyimpangan investasi akan lebih rendah. Hal tersebut dikarenakan berkurangnya asimetri informasi berupa moral hazard dan adverse selection pada laporan keuangan yang disajikan.

Asimetri informasi adalah adanya ketidaksetaraan informasi yang dimiliki oleh pihak manajemen dan pemegang saham (Nurwa \& Purwanto, 2015). Kondisi tersebut terjadi apabila manajer yang memiliki informasi yang lebih lengkap, tidak melaporkannya secara keseluruhan informasi mengenai perusahaan kepada pemegang saham, sehingga dapat memicu tindakan manajer yang menyimpang dalam mengambil keputusan dan menyalahgunakan wewenangnya tanpa sepengetahuan pemegang saham. Menurut Verdi (2006) mengurangi asimetri informasi melalui dua cara yaitu mengurangi asimetri informasi antara perusahaan dengan investor (pemegang saham), dan mengurangi asimetri informasi diantara investor (pemegang saham) dengan cara manajer meningkatkan kualitas dari laporan keuangan.

Laporan keuangan yang menyajikan informasi yang akurat dan jujur tentang posisi laporan keuangan dan kinerja ekonomi perusahaan adalah laporan yang berkualitas (Herath, 2017). Informasi yang akurat dan jujur akan membantu pengguna laporan keuangan dan informasi tersebut akan menjadi dasar dalam setiap pengambilan keputusan ekonomi agar sesuai dengan kondisi perusahaan. Ini berarti informasi yang disajikan diharapkan mampu mempengaruhi keputusan yang diambil oleh pengguna serta menyajikan informasi berupa angkaangka akuntansi dengan tepat. Agar laporan keuangan memiliki kualitas tinggi menurut Gajevszky (2015) laporan keuangan harus transparan, tidak menyesatkan pengguna, serta harus memperhatikan pentingnya ketepatwaktuan dan prediktabilitas.

Penelitian terdahulu berkaitan dengan kualitas laporan keuangan telah dilakukan oleh Chen et. al. (2009) pada private company di Amerika dan Mohammadi (2014) pada perusahaan go public di Malaysia yang menemukan adanya hubungan positif signifikan antara kualitas laporan keuangan dan efisiensi investasi. Rad et al. (2016) meneliti kualitas laporan keuangan perusahaan go public di Tehran yang diproksikan dengan diskresional akrual juga menemukan pengaruh positif kualitas laporan keuangan pada efisiensi investasi. Sedangkan hasil berbeda diperoleh penelitian serupa yang telah dilakukan sebelumnya, yaitu penelitian dari Setyawati (2015) dan Suroso (2017). Kedua penelitian tersebut meneliti perusahaan go public di Indonesia yang hasilnya tidak menemukan adanya pengaruh antara kualitas laporan keuangan dengan efisiensi investasi.

Berdasarkan hasil penelitian tersebut terjadi ketidakkonsistenan antara pengaruh dari kualitas laporan keuangan pada efisiensi investasi. Dimana untuk menyelesaikan perbedaan (ketidakkonsistenan) dari hasil penelitian sebelumnya dapat menggunakan pendekatan kontijensi. Yukl (2010:277) menyebutkan bahwa perbedaan hasil diantara penelitian-penelitian sebelumnya memungkinkan terdapat pengaruh variabel moderating (moderasi). Sehingga, penelitian ini 
menambahkan variabel moderasi untuk menjelaskan ketidakkonsistenan hasil dari beberapa penelitian sebelumnya.

Dalam penelitian ini, kepemilikan asing ditambahkan sebagai variabel moderasi. Chen et al. (2017) dalam penelitiannya pada perusahaan yang baru diprivatisasi menyatakan adanya hubungan positif kepemilikan asing pada efisiensi investasi. Tingkat kepemilikan asing dapat dilihat dari jumlah saham dengan status kepemilikannya oleh pihak luar negeri atau pihak asing yang berstatus individu maupun lembaga asing. Perusahaan dengan investor asing dikenal memiliki kinerja yang lebih baik, menurut Wiranata \& Nugrahanti (2013) hal itu dikarenakan dalam menanamkan modal sahamnya pihak asing memiliki sistem manajemen dan teknologi yang bagus. Sehinga dapat pengaruh positif bagi perusahaan dalam negeri yang memiliki penanam modal asing.

Besarnya risiko yang dihadapi investor asing terkait investasi lintas negara yang dilakukannya juga akan mengakibatkan pengawasan yang lebih baik. Pengawasan yang ketat akan mendorong disajikannya laporan keuangan secara transparan. Kepemilikan asing dalam suatu perusahaan dapat meningkatkan pengawasan, mendorong manajemenuntuk menerapkantata kelola yang efisien dan yang lebih baik dari sebelumnya (Gulamhussen \& Guerreiro, 2009). Perusahaan dengan kepemilikan asing juga menunjukkan tingkat pengembalian asset yang lebih baik saat dibandingkan pada perusahaan dengan kepemilikan domestik. Menurut Ulfiyati et al (2017) pengembalian investasi dari total aktiva menunjukkan tingkat yang lebih baik pada perusahaan dengan struktur kepemilikan asing dibandingkan dengan yang tidak. Dengan demikian, adanya peran dari pihak asing yang tercermin dari jumlah kepemilikan sahamnya di dalam suatu perusahaan mampu memberikan dampak positif khususnya dalam hal investasi.

Penelitian akan dilakukan pada perusahaan go public yaitu yang terdaftar di BEI, yaitu sektor pertambangan. Di Indonesia sendiri, sektor pertambangan adalah salah satu sektor yang diminati asing. Ini dapat terlihat dari data statistik Penanaman Modal Asing (PMA) yang menunjukkan sektor tambang sebagai pemilik jumlah modal asing terbesar dibanding sektor primer lainnya. Data tersebut merupakan data publikasi dari Badan Koordinasi Penanaman Modal (BKPM) di tahun 2017. Jumlah dari modal asing di sektor tersebut yaitu sebesar 4.665,1 juta dolar tahun 2014, 4.017,2 juta dolar tahun 2015, dan 2.742,4 juta dolar pada tahun 2016. Dengan adanya kepemilikan asing yang besar pada sektor pertambangan di Indonesia diharapkan dapat menunjukkan pengaruh positif bagi peningkatan efisiensi khususnya dalam kegiatan investasi yang dilakukan perusahaan.

Penelitian ini bertujuan untuk mengetahui pengaruh kualitas laporan keuangan pada efisiensi investasi dan kemampuan kepemilikan asing dalam memoderasi pengaruh tersebut. Diharapkan pula, penelitian ini dapat memberikan manfaat dalam mendukung teori yang digunakan yaitu teori keagenan serta memberikan informasi bagi pihak-pihak yang berkepentingan terkait dengan efisiensi investasi serta variabel-variabel yang dapat mempengaruhi efisiensi investasi seperti kualitas laporan keuangan dan kepemilikan asing. 
Secara konseptual, Biddle et al. (2009) mendefinisikan apabila sebuah perusahaan melakukan investasi dengan net present value (NPV) positif maka perusahaan tersebut telah berinvestasi secara efisien. NPV adalah nilai dari kegiatan investasi yang menunjukkan selisih antara arus kas yang dihasilkan terhadap biaya investasi yang dikeluarkan. Ketika biaya yang digunakan untuk investasi lebih besar dibandingkan arus kas yang mampu dihasilkan maka proyek tersebut dikatakan memiliki NPV negatif sehingga investasi menjadi tidak layak untuk dilakukan. Sebaliknya, perusahaan harus memilih investasi yang biaya investasi lebih kecil (Pindyck \& Rubinfeld, 2012:361).

Investasi yang menguntungkan dan terhindar dari underinvestment atau overinvestment merupakan jenis investasi yang efisien. Perusahaan akan dikategorikan sebagai underinvestment ketika melewatkan peluang berinvestasi dengan NPV positif. Kondisi overinvestment adalah sebaliknya, yaitu berinvestasi pada investasi dengan NPV negatif. Pengertian lannya menyebutkan, overinvestment merupakan kondisi yang terjadi apabila perusahaan berinvestasi lebih tinggi dari yang diharapkan, hal ini cenderung terjadi pada perusahaan besar yang memilki jumlah modal yang besar pula namun memiliki kesempatan investasi yang sedikit. Sedangkan, kondisi underinvestment terjadi apabila perusahaan melewatkan semua investasi yang dapat memberi keuntungan bagi pihak perusahaan (Rahmawati \& Harto, 2014). Kondisi ini cenderung terjadi pada perusahaan yang mengalami keterbatasan dana untuk diinvestasikan, sehingga kehilangan peluang untuk memperoleh keuntungan dari investasi yang tersedia.

Dalam teori keagenan seseorang investor (principal) akan menunjuk seorang manajer (agent) untuk menjalankan operasional perusahaan akibat adanya keterbatasan principal dalam megelola perusahaan. Pemisahan peran ini rawan untuk memicu timbulnya asimetri informasi (Setyastrini \& Wirajaya, 2017), yaitu kondisi yang terjadi ketika manajer memiliki lebih banyak informasi berkaitan dengan perusahaan dari pada pemengang saham. Dalam teori ini terdapat asumsi bahwa pihak principal dan agent hanya bertindak atas dasar kepentingan mereka masing-masing. Manajer diasumsikan hanya termotivasi untuk meningkatkan insentif atau kompensasi dari kemampuan yang dimiliki dan yang telah dikeluarkan dalam mengelola perusahaan. Seperti yang diungkapkan Verdi (2006) bahwa manajer (agen) dapat memilih untuk berinvestasi secara tidak efisien. Hal tersebut tentu akan merugikan perusahaan dan juga pemegang saham dikarenakan manajer memiliki kewenangan dalam pengambilan sebagian keputusan di dalam perusahaan. Menurut Sansaloni (2015) meningkatnya kualitas laporan keuangan diiringi oleh peningkatan pengendalian internal untuk mencegah timbulmya perilaku oportunistik manajer. Maka, kualitas laporan keuangan yang semakin baik dan jauh dari kecurangan akan mampu mengurangi permasalahan yang timbul akibat teori keagenan.

Menurut Nurcholisah (2016) kualitas informasi keuangan adalah informasi penting dalam membuat keputusan investasi. Kualitas laporan keuangan merupakan indikator yang dapat menunjukkan baik tidaknya kemampuan perusahaan dalam mengelola sumber dayanya, salah satunya kemampuan perusahaan dalam hal mengelola modal yang dimiliki untuk kebutuhan investasi. Perusahaan dengan kualitas pelaporan yang lebih tinggi menunjukkan tingkat 
efisiensi investasi yang lebih baik yang diproksikan dengan tingkat yang lebih rendah pada sensitivitas arus kas investasinya (Biddle et al., 2009).

Penelitian lainnya juga menemukan bahwa kualitas pelaporan keuangan yang tinggi membantu perusahaan dalam menghindari terjadinya kondisi underinvestment maupun kondisi overinvestment (Chen et al.,2011). Dengan kata lain perusahaan akan dapat terhindar dari inefisiensi investasi. Sejalan dengan hasil penelitian tersebut, Mohammadi (2014) dan Rad et al. (2016) menemukan bahwa kualitas laporan keuangan dapat meningkatkan efisiensi investasi. Namun, beberapa penelitian seperti yang dilakukan Setyawati (2015) dan Suroso (2017) tidak menemukan adanya pengaruh kualitas laporan keuangan terhadap efisiensi investasi. Oleh karena itu, maka diajukan hipotesis yang pertama.

$\mathrm{H}_{1}$ : Kualitas laporan keuangan berpengaruh positif pada efisiensi investasi.

Kepemilikan asing di dalam suatu perusahaan tercermin dari jumlah kepemilikan saham oleh pihak asing, baik yang dimiliki oleh individu, maupun lembaga. Di dalam struktur kepemilikan perusahaan, peran pihak tersebutdapat mempengaruhi manajemen untuk melakukan transparansi dalam pelaporan keuangannya. Dengan adanya transparasi maka kesalahan dalam penyajian laporan keuangan dapat diminimalisir. Menurut Chen et al. (2017) kepemilikan asing dapat membantu perusahaan meningkatkan efisiensi investasinya dikarenakan kepemilikan asing dapat meminimalisir masalah agensi dan asimetri informasi dengan carameningkatkan corporate governance dan transparansi keuangan. Penelitian Chen et al. (2017) yang dilakukan pada perusahaan yang telah diprivatisasi menemukan adanya kecenderungan pengaruh yang lebih kuat antara perusahaan dengan kepemilikan asing pada tingkat efisiensi investasi. Sejalan dengan penelitian tersebut, Hapsari (2015) menemukan adanya pengaruh positif signifikan antara kepemilikan asing pada efisiensi investasi. Sehingga, diajukan hipotesis kedua.

$\mathrm{H}_{2}$ : Kepemilikan asing memperkuat pengaruh hubungan kualitas laporan keuangan pada efisiensi investasi.

\section{METODE PENELITIAN}

Pendekatan kuantitatif yang digunakan membutuhkan data berupa angkaangkayang akan digunakan untuk mengetahui hubungan antar variabel yang diteliti. PT. Bursa Efek Indonesia (BEI) dipilih sebagai lokasi penelitian. Data yang diperlukan diperoleh dengan analisa terhadap laporan keuangan perusahaanyang telah tersedia pada website yaitu www.idx.co.id. BEI sebagai lembaga pasar modal di Indonesia menyediakan informasi dan data yang terkait dengan perusahaan-perusahaan yang telah go public. Jumlah keseluruhan perusahaan sektor pertambangan yang ada berjumlah 42 perusahaan dengan tiga tahun pengamatan yaitu tahun 2014-2016.

Dalam penentuan sampel, terdapat kriteria yang dipergunakan. Perusahaan tambang yang mempublikasikan laporan tahunannya pada periode pengamatan yaitu 2014-2016. Perusahaan tambang yang mempublikasikan datadata yang diperlukan untuk mengukur variabel efisiensi investasi, kualitas laporan keuangan dan kepemilikan asing. Adapun sampel yang diperoleh sebanyak 15 perusahaan sektor pertambangan terdiri dari dari empat subsektor yang berbeda-beda. Jumlah perusahaan yang dijadikan sampel dari masing- 
masing subsektor tersebut sebanyak 9 perusahaan dari subsektor I yaitu Batubara, 3 perusahaan dari subsektor II yaitu Minyak \& Gas Bumi, 2 perusahaan dari subsektor III yaitu Logam \& Mineral, dan 1 perusahaan dari subsektor IV yaitu Batu-Batuan. Hasil seleksi pemilihan sampel pada penelitian ini tersaji pada tabel berikut.

Tabel 1. Hasil Seleksi Pemilihan Sampel

\begin{tabular}{ll}
\hline Kriteria & $\begin{array}{l}\text { Jumlah } \\
\text { Perusahaan }\end{array}$ \\
\hline $\begin{array}{l}\text { Populasi dalam penelitian adalah perusahaan pertambangan yang } \\
\text { terdaftar di Bursa Efek Indonesia periode 2014-2016 }\end{array}$ & 42 \\
$1 \quad \begin{array}{l}\text { Perusahaan yang tidak menerbitkan laporan tahunan secara } \\
\text { berturut-turut selama periode pengamatan yaitu 2014-2016 }\end{array}$ & $(3)$ \\
$\begin{array}{l}\text { (akibat suspend) } \\
\text { Perusahaan yang tidak mencantumkan data-data yang }\end{array}$ & $(24)$ \\
$\begin{array}{l}\text { lengkap terkait dengan kepemilikan saham (shareholders } \\
\text { information) yang digunakan dalam penelitian ini }\end{array}$ & \\
Total perusahaan yang dijadikan sampel & 15 \\
Total sampel selama tahun 2014-2016 & 45 \\
\hline
\end{tabular}
Sumber: Data Penelitian, 2018

Dalam mengumpulkan data digunakan observasi nonparticipant. Dikarenakan peneliti hanya melakukan observasi dan pengamatan secara independen dan tidak terlibat secara langsung. Penelitian ini memperoleh data berupa variabel kualitas laporan keuangan, kepemilikan asing, dan efisiensi investasi melalui laporan tahunan dari perusahaan pertambangan yang dipublikasikan padawebsite resmi BEI. Kualitas laporan keuangan sebagai variabel independen diproksikan dengan kualitas akrual yang digunakan oleh Kothari, et al. (2005). Model pengukurannya adalah sebagai berikut.

$T A_{i, t}=\alpha_{0}+\alpha_{1}\left[1 /\right.$ ASSETS $\left._{i, t-1}\right]+\alpha_{2} \Delta$ SALES $_{i, t}+\alpha_{3} P P E_{i, t}+\alpha_{4} R O A_{i, t(\text { or } i, t-1)}+\varepsilon_{i, t} \ldots \ldots . .(1)$ Keterangan:

$T A_{i, t}=$ ukuran mengenai total accrual perusahaan pada periode tertentu $\operatorname{ASSETS~}_{i, t-1} \quad=$ total asset perusahaan pada periode sebelumnya

$\triangle S A L E S_{i, t} \quad=$ besarnya perubahan penjualan perusahaan

Untuk memproleh nilai residual maka dilakukan perhitungan dari masingmasing variabel sebagai ukuran dari kualitas laporan keuangan.

$T A_{i, t}=$ Net Income - Cashflow from Operation

$\triangle$ SALES $_{i, t}=$ Sales $_{t}-$ Sales $_{t-1}$

$R O A_{i, t}=\frac{\text { Net Income }}{\text { Total Assets }}$

$P P E_{i, t} \quad=$ Harga Porolehan Aktiva Tetap - Depresiasi Aktiva Tetap

Agar terhindar dari heteroskedastisitas pada nilai residual yang akan diperoleh maka selanjutnya dilakukan perhitungan dengan membagi seluruh variabel untuk pengukuran kualitas laporan keuangan dengan. Dengan demikian, maka untuk memperoleh nilai residual dapat dilihat dalam persamaan berikut ini.

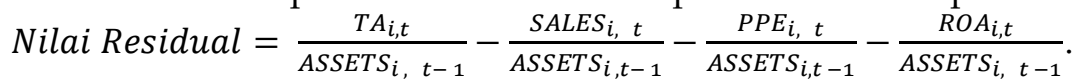

Persamaan di atas akan menunjukkan nilai residual yang merupakan nilai diskresional akrual dari laporan keuangan. Nilai tersebut kemudian diabsolutkan sehingga memperoleh nilai absolut dari diskresional akrual dengan dikalikan -1, hal ini dikarenakan pada penelitian Dechow \& Dichev (2002) yang menjadi 
perhatian hanyalah besaran dari discretionary accrual, dan bukan arah positif maupun negatifnya. Sehingga nilai tertinggi yang diperoleh dari pengukuran tersebut akan menunjukkan kualitas pelaporan keuangan yang lebih baik.

Kepemilikan asing sebagai variabel moderasi dalam penelitian inidiharapkan mampu memperkuat maupun memperlemah hubungan di antara kualitas laporan keuangan dengan efisiensi investasi. Kepemilikan asing menghitung besarnya kepemilikan saham pihak asing dalam perusahaan, baik yang dimiliki oleh individu maupun lembaga. Perusahaan yang memiliki kepemilikan asing akan dimasukkan ke dalam sampel. Data tersebut diperoleh melalui laporan tahunan perusahaan terkait. Variabel kepemilikan asing digunakan dalam penelitian ini diperoleh dengan menghitung keseluruhan saham dari pemilik asing Anggraini (2011). Rumusnya adalah sebagai berikut.

$F O=\frac{\text { sahan yang dimiliki asing }}{\text { total jumla saham yang beredar }}$.

Efisiensi investasidalam penelitian ini menggunakan pengukuran investasi yang berfungsi sebagai growth opportunities. Pada penelitian sebelumnya, Biddle et al. (2009) telah menggunakan persamaan ini untuk mengukur efisiensi investasi. Tujuannya untuk memprediksikan tingkat investasi yang diharapkan perusahaan di tahun tertentu yaitu diukur dengan pertumbuhan penjualan. Model pengukurannya adalah sebagai berikut.

Investment $_{i, t+1}=\beta_{0}+\beta_{1} *$ Sales Growth $_{i, t}+e_{i, t+1}$

Keterangan:

Investment $_{i, t+1}=$ total keseluruhan investasi aktiva tetap

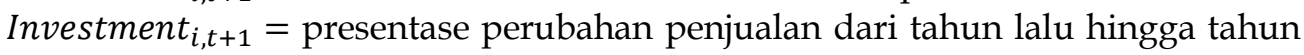
ini

Nilai residual yang diperoleh dari persamaan di atas akan menunjukkan besarnya tingkat penyimpangan atau deviasi. Nilai tersebut memperlihatkan seberapa besar penyimpangan dari efisiensi investasi yang ditentukan perusahaan. Nilai tersebut digunakan sebagai pengukuran variabel efisiensi investasi. Dalam penelitian ini nilai residualdiabsolutkan dengan dikalikan -1. Sehingga, dapat menunjukkan bahwa semakin tinggi nilai yang diperoleh maka investasi yang dilakukan perusahaan semakin efisien.

Dalam menguji hipotesis penelitian akan digunakan dua teknik analisis data, yang pertama analisis regresi linier sederhana regresi yang akan digunakan untuk menguji pengaruh kualitas laporan keuangan pada efisiensi investasi. Analisis kedua yaitu analisis regresi moderasi yang akan digunakan untuk menguji variabel moderasi kepemilikan asing pada pengaruh kualitas laporan keuangan dengan efisiensi investasi. Berikut persamaan dari masing-masing teknik analisis yang digunakan.

$Y=\beta_{0}+\beta_{1} x_{1}+\varepsilon$

$Y=\beta_{0}+\beta_{1} x_{1}+\beta_{2} x_{2}+\beta_{3}\left(x_{1} x_{2}\right)+\varepsilon$

Keterangan:

$Y \quad=$ efisiensi investasi

$\beta_{0} \quad=$ konstanta

$\beta_{(1,2)} \quad=$ koefisien regresi

$\beta_{3} \quad=$ koefisien interaksi

$\mathrm{X}_{1} \quad=$ kualitas laporan keuangan 


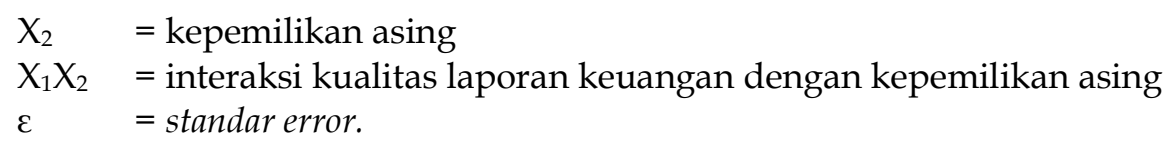

\section{HASIL DAN PEMBAHASAN}

Untuk memberikan deskripsi terhadap data penelitian, berikut adalah hasil dari analisis statistik deskriptif dari variabel kualitas laporan keuangan, kepemilikan asing, dan efisiensi investasi.

Tabel 2. Hasil Statistik Deskriptif

\begin{tabular}{|c|c|c|c|c|c|}
\hline & $\mathrm{N}$ & Minimum & Maximum & Mean & Std. Deviation \\
\hline $\begin{array}{l}\text { Kualitas Laporan } \\
\text { Keuangan }\end{array}$ & 45 & 0,06 & 1,44 & 0,495 & 0,335 \\
\hline Kepemilikan Asing & 45 & 4,96 & 90,44 & 27,719 & 23,251 \\
\hline Efisiensi Investasi & 45 & $-1,05$ & 0,00 & $-0,440$ & 0,240 \\
\hline Valid N & 45 & & & & \\
\hline
\end{tabular}

Sumber: Data Penelitian, 2018

Tabel 2, menunjukkan rata-rata dari variabel kualitas laporan keuangan yaitu 0,4950 , nilai minimumnya 0,06 dan nilai maksimumnya 1,44 . Nilai rata-rata sebesar 0,4950 yang lebih mendekati 1,44 menunjukkan bahwa ada lebih sedikit sampel perusahaan yang menyajikan laporan keuangan yang berkualitas rendah. Kualitas laporan keuangan yang paling rendah (minimum) sebesar 0,06 berasal dari data tahun 2014 Indo Tambangraya Tbk. Sedangkan kualitas laporan keuangan paling tinggi (maksimum) sebesar 1,44 dimiliki oleh Darma Henwa Tbk pada tahun 2015. Standar deviasi kualitas laporan keuangan menunjukkan bahwa terjadi penyimpangan sebesar 0,33518 terhadap nilai rata-ratanya.

Nilai rata-rata variabel kepemilikan asing yaitu 27,719 dengan nilai minimumnya 4,96 dan nilai maksimumnya 90,44. Nilai rata-rata sebesar 27,719 yang cenderung lebih mendekati nilai minimum menunjukkan hanya ada sedikit perusahaan dengan kepemilikan asing yang tinggi. Kepemilikan asing yang paling rendah (minimum) sebesar 4,96. Standar deviasi kepemilikan asing menunjukkan bahwa terjadi penyimpangan sebesar 23,251 terhadap nilai rataratanya.

Nilai rata-rata variable lefisiensi investasi yaitu $-0,440$ dengan nilai minimumnya-1,05 sedangkan nilai maksimumnya 0,00 . Dari nilai rata-ratanya yang cenderung lebih mendekati nilai minimum menunjukkan ada lebih sedikit perusahaan dengan tingkat efisiensi investasi yang tinggi. Efisiensi investasi yang paling rendah (minimum) sebesar -1,05 dimiliki oleh Apexindo Pratama Duta Tbk pada tahun 2016. Sedangkan efisiensi investasi paling tinggi (maksimum) sebesar 0,00 dimiliki oleh Mitra Investindo Tbk pada tahun 2014. Standar deviasi efisiensi investasi menunjukkan bahwa terjadi penyimpangan sebesar 0,240 terhadap nilai rata-ratanya. Adapun persamaan yang diperoleh dari tabel analisis regresi di atas adalah sebagai berikut.

$$
\mathrm{Y}=5,538+0,836 \mathrm{X}_{1}
$$

Konstanta (a) sebesar 5,538 menyatakan bahwa jika variabel kualitas laporan keuangan $\left(\mathrm{X}_{1}\right)$ konstan, maka efisiensi investasi $(\mathrm{Y})$ yang diproksikan dengan growth opportunities adalah sebesar 5,538 satuan. Sedangkan, nilai koefisien regresi $\left(\beta_{1}\right)$ dari kualitas laporan keuangan $\left(X_{1}\right)$ sebesar 0,836 ini berarti bahwa 
apabila kualitas laporan keuangan meningkat sebesar 1 satuan, maka efisiensi investasi (Y) yang diproksikan dengan growth opportunities akan meningkat sebesar 0,836 . Analisis regresi linier sederhana dilakukan dengan bantuan dari program SPSS. Hasil dari analisis regresi yang dilakukan tersaji pada Tabel 3.

Tabel 3. Hasil Analisis Regresi Linear Sederhana

\begin{tabular}{llllll}
\hline \multirow{2}{*}{ Model } & \multicolumn{3}{c}{$\begin{array}{c}\text { Unstandardized } \\
\text { Coefficients }\end{array}$} & $\begin{array}{c}\text { Standardized } \\
\text { Coefficients }\end{array}$ & \\
\cline { 2 - 4 } & $\mathrm{B}$ & Std. Error & Beta & T & Sig. \\
\hline 1 (Constant) & 5,538 & 0,083 & & 0,000 & 1,000 \\
$\quad$ Kualitas Laporan Keuangan & 0,836 & 0,084 & 0,0836 & 9,992 & 0,000 \\
R Square & 0,699 & & & & \\
Adjusted R Square & 0,692 & & & & \\
F Hitung & 99,834 & & & & \\
Signifikansi F & 0,000 & & & & \\
\hline
\end{tabular}

Sumber: Data Penelitian, 2018

Pada Tabel 3, juga dapat dilihat hasil uji F (Ftest) yang menunjukkan layak atau tidaknya model yang digunakan dalam penelitian. Dilihat dari nilai signifikansi $\mathrm{F}$ yaitu 0,000 memiliki arti bahwa model yang digunakan adalah layak. Sebab nilai signifikansi F lebih kecil dari ayaitu 0,05. Hal ini menunjukkan bahwa variabel kualitas laporan keuangan, dapat menjelaskan fenomena dari variabel dependen pada perusahaan yang diteliti. Yaitu sektor pertambangan go public tahun 2014-2016. Nilai adjusted $R^{2}$ menunjukkan koefisien determinasi dari regresi yang dilakukan. Nilainya yang sebesar 0,692 berarti variasi efisiensi investasi dapat dipengaruhi oleh variabel kualitas laporan keuangan sebesar 69,2 persen sedangkan 30,8 persen merupakan pengaruh faktor lainnya.

Hipotesis pertama yaitu kualitas laporan keuangan memiliki pengaruh positif pada efisiensi investasi. Hasil pengujian pada Tabel 3, menunjukkan kualitas laporan keuangan yang diukur dengan kualitas akrual memiliki koefisien regresi positif sebesar 0,836 dengan nilai signifikansi 0,000. Nilai tingkat signifikansi yang kurang dari 0,05 yang berarti $\mathrm{H}_{1}$ diterima. Hal ini menunjukkan bahwa variabel kualitas laporan keuangan memiliki pengaruh positif terhadap efisiensi investasi.

Untuk menguji hipotesis kedua atau untuk mengetahui apakah variabel kepemilikan asing mampu memoderasi pengaruh variabel kualitas laporan keuangan terhadap efisiensi investasi, maka dilakukan pengujian selanjutnya yaitu menggunakan model pengujian Moderated Regression Analysis (MRA). Pengujian ini tujuannyauntuk mengetahui apakah kepemilikan asing mampu mempengaruhi hubungan antara kualitas laporan keuangan pada efisiensi investasi. Model ini dalam dalam persamaan regresinya mengandung unsur interaksi. Interaksi tersebut merupakan hasil kali antara nilai dari kualitas laporan keuangan dan kepemilikan asing. Berdasarkan Tabel 4, maka diperoleh persamaan regresi berikut ini.

$$
Y=1,297+1,199 X_{1}-0,018 X_{2}+0,419 X_{1} X_{2}+\varepsilon
$$

Nilai dari $\left(\beta_{3}\right)$ merupakan koefisien regresi interaksi dari kualitas laporan keuangan dengan kepemilikan asing. Koefisien regresi bernilai positif sebesar 0,419 memiliki arti apabila setiap interaksi kualitas laporan keuangan dengan kepemilikan asing meningkat sebesar 1 satuan, maka efisiensi investasi ( $Y$ ) 
jugameningkat yaitu sebesar 0,419 satuan. Berikut adalah hasil dari analisis regresi moderasi yang dilakukan hasilnya disajikan pada Tabel 4.

Tabel 4. Hasil Analisis Interaksi atau Moderated Regression Analysis (MRA)

\begin{tabular}{|c|c|c|c|c|c|}
\hline \multirow[t]{2}{*}{ Model } & \multicolumn{2}{|c|}{$\begin{array}{l}\text { Unstandardized } \\
\text { Coefficients }\end{array}$} & \multirow{2}{*}{$\begin{array}{c}\text { Standardized } \\
\text { Coefficients } \\
\text { Beta }\end{array}$} & \multirow[b]{2}{*}{$\mathrm{T}$} & \multirow[b]{2}{*}{ Sig. } \\
\hline & B & Std. Error & & & \\
\hline 1 (Constant) & 1,297 & 0,078 & & 0,000 & 1,000 \\
\hline Kualitas Laporan Keuangan & 1,199 & 0,202 & 1,199 & 5,923 & 0,000 \\
\hline Kepemilikan Asing & $-0,018$ & 0,102 & $-0,018$ & $-0,181$ & 0,857 \\
\hline $\mathrm{X}_{1} . \mathrm{X}_{2}$ (Interaksi) & 0,419 & 0,205 & 0,419 & 2,043 & 0,048 \\
\hline$R$ Square & & & & & 0,747 \\
\hline Adjusted R Square & & & & & 0,728 \\
\hline F Hitung & & & & & 40,308 \\
\hline Signifikansi F & & & & & 0,000 \\
\hline
\end{tabular}

Sumber: Data Penelitian, 2018

Pada Tabel 4, menunjukkan hasil uji $\mathrm{F}$ (Ftest) yaitu nilai signifikansi Fsebesar 0,000 yang lebih kecil dari nilai a $(0,05)$, ini berarti model yang digunakan pada penelitian ini adalah layak. Hal ini menunjukkan bahwa seluruh variabel independen yaitu kualitas laporan keuangan, kepemilikan asing, dan variabel interaksi antara kualitas laporan keuangan dengan kepemilikan asing mampu memprediksi atau menjelaskan fenomena efisiensi investasi.

Dari Tabel 4, dari nilai adjusted $\mathrm{R}^{2}$ sebesar 0,728 merupakan koefisien determinasi yang memiliki arti bahwa variasi efisiensi investasi dapat dipengaruhi secara signifikan oleh variabel kualitas laporan keuangan, kepemilikan asing, dan variabel interaksi antara kualitas laporan keuangan dengan kepemilikan asing sebesar 72,8 persen sehingga 27,2 persen sisanya menunjukkan bahwa variabel dependen dijelaskan oleh faktor-faktor lain. Dapat dilihat pula bahwa pada pengujian dengan teknik analisis kedua ini memiliki nilai nilai koefisien determinasi yang lebih besar dibandingkan pada pengujian pertama. Hal ini dikarenakan adanya penambahan variabel yang digunakan yaitu kepemilikan asing.

Hipotesis kedua yaitu kepemilikan asing memperkuat pengaruh hubungan kualitas laporan keuangan pada efisiensi investasi. Dilihat dari hasil pengujian pada Tabel 4 yaitu koefisien interaksi yang besarnya 0,419 sedangakan signifikansi besarnya 0,048. Nilai tingkat signifikansi yang kurang dari 0,05 yang berarti $\mathrm{H}_{2}$ diterima. Sehingga, variabel kepemilikan asing memperkuat pengaruh hubungan kualitas laporan keuangan pada efisiensi investasi.

\section{SIMPULAN}

Analisis regresi yang telah dilakukan menunjukkan bahwa kualitas laporan keuangan berpengaruh positif pada efisiensi investasi. Semakin baik kualitas dari suatu laporan keuangan, maka akan dapat meningkatkan efisiensi investasi dari perusahaan tersebut. Hal ini juga mengindikasikan bahwa peningkatan terhadap kualitas laporan keuangan mampu mengurangi asimetri informasi yang ditimbulkan dari adanya hubungan agensi antara manajer dan pemegang saham.

Adanya kepemilikan asing juga menunjukkan pengaruh positif terhadap hubungan kualitas laporan keuangan pada efisiensi investasi. Hal ini mengindikasikan bahwa keikutsertaan pihak asing dalam kepemilikan 
perusahaan mampu meningkatkan pengawasan di dalam perusahaan. Pihak asing dapat mempengaruhi manajemen untuk menerapkan teknologi dan tata kelola yang lebih baik sehingga kesalahan dalam penyajian laporan keuangan dapat diminimalisir. Dan kualitas dari informasi yang tersaji dalam laporan keuangandapat ditingkatkan (Syamsudin et al., 2017). Sehingga, dengan adanya kepemilikan asing dalam suatu perusahaan dapat mempengaruhi tingkat efisiensi investasi menjadi lebih baik dengan peningkatan terhadap kualitas informasi laporan keuangan melalui transparansi dan pengawasan.

Berdasarkan pembahasan yang telah diuraikan, diharapkan penelitian ini memberikan dampak positif bagi semua pihak khususnya bagi investor dan perusahaan. Bagi pihak perusahaan agar lebih memperhatikan kualitas laporan keuangan yang akan disajikan. Selain itu, untuk perusahaan dengan kepemilikan asing agar lebih memaksimalkan peran institusi asing dalam mengawasi jalannya operasional perusahaan untuk tujuan meningkatkan efisiensi investasi serta referensi bagi investor di dalam melakukan investasi di pasar modal. Agar investor memperhatikan faktor yang dapat mempengaruhi tingkat efisiensi investasi misalnya seperti kualitas laporan keuangan yang dicerminkan dengan kualitas akrualnya.

Penelitian terkait efisiensi investasi masih perlu banyak dilakukan. Kekurangan penelitian ini terkait jumlah sampel yang kecil dapat menjadi pertimbangan dilakukan penelitian-penelitian selanjutnya dengan memperluas populasi penelitian. Selain itu, juga dapat menggunakan perusahaango public pada sektor lainnya untuk menguji variabel-variabel tersebut terutama pengaruh variabel kepemilikan asing terhadap efisiensi investasi yang masih sedikit diteliti. Selain itu, juga dapat menambahkan variabel bebas dan variabel moderasilainnya yang diduga dapat mempengaruhi efisiensi investasi.

\section{REFERENSI}

Anggraini, Ririn Dwi. (2011). Pengaruh Kepemilikan Institusional dan Kepemilikan Asing Terhadap Pengungkapan Pertanggungjawaban Sosial Perusahaan dalam Annual Report (Studi Empiris Pada Perusahaan Non Keuangan Yang Tercatat di BEI Tahun 2008-2009). Diponegoro Journal of Accounting.

Biddle, G., Hilary, G., Verdi, R.S. (2009). How Does Financial Reporting Quality Relate to Investments Efficiency? Journal of Accounting and Economics, 48, pp. 112-131.

Chen, F., Hope, O., Li, Q., Wang, X. (2011). Financial Reporting Quality and Investment Efficiency of Private Firms In Emerging Markets. The Accounting Review, 86, pp. 1255-1288.

Chen, Ruiyuan, Sadok El Ghoul, Omrane Guedhami, He Wang. (2017). Do State and Foreign Ownership Affect Investment Efficiency? Evidence from Privatizations. Journal of Corporate Finance, 42, pp. 408-421.

Dechow, P., Dichev, I., (2002). The Quality of Accruals and Earnings: The Role of Accrual Estimation Errors. The Accounting Review, 77, pp. 35-59.

Emayanti, Ida Ayu Agung. (2016). Efisiensi Investasi Sebagai Pemoderasi Pengaruh Kualitas Laporan Keuangan pada Asimetri Informasi di Perusahaan Pertambangan. Skripsi. Universitas Udayana. 
Firth, M., Lingmin Xie, Yuanyuan Zhang. (2015). How Do Analysts' Forecast Characteristics Relate to Investment Efficiency? Department of Finance and Insurance, Lingnan University, Hong Kong.

Gajevszky, Andra. (2015). Assessing Financial Reporting Quality: Evidence from Romania. Audit Financiar, pp. 1583-5812.

Gulamhussen, M. A., \& Guerreiro, L. (2009). The Influence of Foreign Equity and Board Membership on Corporate Strategy and Internal Cost Management in Portuguese Banks. Management Accounting Research, 20(1), pp. 6-17.

Hapsari, Angela Aprilia. (2015). Pengaruh Kualitas Laporan Keuangan, Kepemilikan Asing, Frekuensi Pertemuan Komite Audit, dan Spesialisasi Industri Auditor terhadap Efisiensi Investasi. Skripsi. Fakultas Ekonomi dan Bisnis Universitas Katolik Soegijapranata

Herath, S., Norah Albarqi. (2017). Financial Reporting Quality: A Literature Review. International Journal of Business Management and Commerce, 2(2), pp. $1-14$.

Ikatan Akuntan Indonesia (IAI). (2016). Exposure Draft: Kerangka Konseptual Pelaporan Keuangan. Jakarta: Dewan Standar Akuntansi Keuangan.

Kothari, S.P., Leone, A.J., \& Wasley, C.E. (2005). Performance Matched Discretionary Accrual Measures. Journal of Accounting and Economics, 39, pp. 163-117.

Li, Qingyuan dan Tielin Wang. (2010). Financial Reporting Quality and Corporate Investment Efficiency: Chinese Experience. Nankai Business Review International, 1(2), pp. 197-213.

Mith, Abhipraya. (2017). Prospek \& Risiko Bisnis Tambang Batubara Indonesia dan Strategi Perusahaan Tambang \& Strategi Perbankan 2017. www.linkedin.com/share.php? $u=$. Diunduh tanggal 3 Mei 2018.

Mohammadi, Seyed Moosa. (2014). The Relationship Between Financial Reporting Quality and Investment Efficiency in Tehran Stock Exchange. International Journal of Academic Research in Business and Social Sciences,4(6), pp. 104-113.

Nurcholisah, Kania. (2016). The Effects of Financial Reporting Quality on Information Asymmetry and Its Impacts On Investment Efficiency.International Journal of Economics, Commerce and Management United Kingdom, IV(5), pp. 838-850.

Nurwa, Risha Aristiani \& Agus Purwanto. (2015). Pengaruh Kualitas Laba Akuntansi Terhadap Efisiensi Investasi Perusahaan dengan Risiko Litigasi Sebagai Variabel Moderating (Studi Empiris pada Perusahaan Manufaktur yang Terdaftar Di BEI Tahun 2011-2012). Diponegoro Journal of Accounting, 4(3), hal.1-11.

PwC Media Centre. (2016). Tahun 2015 Sebagai Tahun Terburuk Bagi Sektor Pertambangan.https://www.pwc.com/id/en/media-centre/pwc-innews/2016/indonesian/pwc---tahun-2015-sebagai-tahun-terburuk-bagi-sektorpertambangan.html. Diunduh tanggal 30 Maret 2018.

Pindyck, S. R., Daniel L. Rubinfeld. (2012). Mikroekonomi Edisi Kedelapan. Jakarta: Erlangga.

Rad, Seyed Sajad Ebrahimi, Zaini Embong, Norman Mohd-Saleh, Romlah Jaffar. (2016). Financial Information Quality and Investment Efficiency: Evidence 
From Malaysia. Asian Academy of Management Journal of Accounting and Finance, 12(1), pp.129-151.

Rahmawati, Anisa Dwi \& Puji Harto. (2014). Analisis Pengaruh Kualitas Pelaporan Keuangan dan Maturitas Utang Terhadap Efisiensi Investasi. Diponegoro Journal of Accounting, 3(3), hal.1-12

Republika. (2017). Sektor Pertambangan Butuh Investor Asing. http://m.republika.co.id/berita/ekonomi/makro/17/10/30/oymyf1423-sektor pertambangan-butuh-investasi-asing $E$ grqid $=0 d \mathrm{zOPP} 4 \& \mathrm{~s}=1 \& \mathrm{kl}=\mathrm{id}-\mathrm{ID}$.

Diunduh tanggal 16 Januari 2018

Sansaloni Butar Butar. (2015). Dampak Kualitas Laporan Keuangan, Regulasi Pengendalian Internal dan Keterbatasan Keuangan Terhadap Inefisiensi Investasi. Jurnal Akuntansi dan Keuangan, 17(1), Mei 2015, hal. 57-70.

Sari, L. Indah Novita \& I G.N.A. Suaryana. (2014). Pengaruh Kualitas Laporan Keuangan pada Efisiensi Investasi Perusahaan Pertambangan. E-Jurnal Akuntansi Universitas Udayana, 8(3), hal. 524-537.

Setyawati, Lucia Jeni. (2015). Kualitas Informasi Pelaporan Keuangan: FaktorFaktor Penentu dan Pengaruhnya Terhadap Efisiensi Investasi. Jurnal Ekonomi dan Bisnis, XXV(2), hal. 186-196.

Sugiyono. (2016). Statistka untuk Penelitian. Bandung: Alfabeta.

Suroso, Michael Armando. (2017). Pengaruh Konservatisme dan KualitasPelaporan Keuangan Terhadap Efisiensi Investasi dengan Kepemilikan Institusional Sebagai Variabel Moderasi. Skripsi. Fakultas Bisnis Fakultas BisnisUniversitas Katolik Widya Mandala.

Syamsudin, S., Imronudin, I., Utomo, S. T., Prakoso, S. T., \& Praswati, A. N. (2017). Tata Kelola Korporasi dalam Mendeteksi Kecurangan Laporan Keuangan. Jurnal Manajemen Dayasaing, 19(1), hal. 63-73.

Ulfiyati, Linda Lambey, Stanley Kho Walandouw. (2017). Analisis Perbedaan Struktur Kepemilikan Asing dan Struktur Kepemilikan Domestik Pada Perusahaan Pertambangan Di Bursa Efek Indonesia. Jurnal EMBA, 5(2), hal. 2260-2267

Verdi, R.S. (2006). Financial Reporting Quality and Investment Efficiency. Working Paper. http://ssm.com/abstract=930922. Diunduh tanggal 30 Maret 2018.

Willan, Holman Fenwick. (2013). Global Risk and Insurance Guide 2014. London: Aspermont Media

Wiranata, Yulius Ardy \& Yeterina Widi Nugrahanti. (2013). Pengaruh Struktur Kepemilikan Terhadap Profitabilitas Perusahaan Manufaktur di Indonesia. Jurnal Akuntansi dan Keuangan, 15(1), hal.15-26.

Yukl, Gary. (2010). Kepemimpinan dalam Organisasi, Edisi Kelima. Jakarta: PT. Indeks. 